\title{
Board of Directors" "Convexification" and Corporate Results: Recent Evidence from Italy under a Linear/PLS Approach
}

\author{
Marco Taliento $^{1}$, Christian Favino ${ }^{1} \&$ Angelo Fiorella $^{1}$ \\ ${ }^{1}$ Department of Economics, University of Foggia, Foggia, Italy \\ Correspondence: Marco Taliento, Department of Economics, University of Foggia, Via Caggese 1, 71121 Foggia, \\ Italy. Tel: 39-0881-781736. E-mail: marco.taliento@unifg.it
}

Received: April 21, 2017

Accepted: June 20, 2017

Online Published: July 18, 2017

doi:10.5539/ijbm.v12n8p100

URL: https://doi.org/10.5539/ijbm.v12n8p100

\begin{abstract}
We investigate how the attributes of the board of directors are related to results in the case of top capitalised companies listed on "Borsa Italiana" (2014 to 2016). Consistently with an integrated (agency and resource/stewardship) framework, we provide the assumptions and main statistics, then execute the econometric modelling: the composition and function board's profiles are used as explanatory variables and the firms' performance as response variable. In a first phase, we verified the possible 'role' of the key characteristics with accounting and economic performances (OLS) even controlling for the ability to create additional value. In a second phase, we adopted - for the first time in this issue - a SEM approach along a Partial Least Squares path (PLS: a variance-based model increasingly applied in business and social sciences), considering "performance" and "organisational convexity" as the latent operationalised variables. Interesting findings emerged from the research (negative influence of the number of meetings and committees, \% of independent members and age of $\mathrm{CEO}$; vs positive influence of external offices, CEO duality and presence of women in the boardroom), allowing new and partly counterintuitive understanding about the governance / performance linkage. In the context of the late post-crisis, our latent variables appear negatively related: corporate performance is higher in presence of an organisational concavity inspired to efficiency-oriented synthesis and concentration/centralisation of competencies, with a curved-in yet resilient, svelte and effective array, rather than a more structured one (that is: deconvexification would provide value), suggesting a shift from the general market-to-board approach to a specific board-to-market approach characterised by strong and influential leadership, interests alignment, high trust and clear commitment.
\end{abstract}

Keywords: board of directors, corporate governance, performance, structural equations modeling

\section{Introductory Notes}

We aim to investigate the interesting combination between business administration and performance, sometimes "taken for granted" (as self-evident) by corporate governance and accounting / valuation literature and practice. (Note 1)

The starting point of the study is the idea of analysing the "'incisiveness" of the board of directors, generally considered among the leading - if not the primary - corporate governance protagonists. It is even known that corporate governance (Gillian, 2006; Huse, 2007; Shleifer \& Vishny, 1997; Turbull, 2012; Zattoni, 2015; Zingales, 2008) is built on complex inter-organisational (management and control) relationships, which basically involve policies that strive to bring order on the crucial issues and dynamics for the enterprise institute such as resource flows and knowledge, stakeholders' interests, remuneration, powers, duties and responsibilities, as they emerge in the context of the relational triangle that essentially combines business ownership (shareholders), the board of directors and management. Triangle whose natural gravity center can be detectable - in our opinion right in the board. (Note 2)

It is also common knowledge that each "governance" system is intimately oriented towards the objective of generating positive performance and, ultimately, supporting the value creation (Onesti et al., 2013; Zanda et al., 2013). In this regard, it seems incontrovertible the core role of the administrative body in the business results and going concern value processes. While recognizing that such processes are de facto "unitary" and involve, simultaneously and subsequently (seamless) several organisational actors (including the ownership or control group and the top executive management), we try to isolate the corporate board contribution to financial 
performance; and this by virtue of its factual, structural and functional qualities, being able to reverberate - in the current economic environment where businesses operate - on performance.

Accordingly, the structure of the rest of the work is the following: after a brief illustration of the literature background, we proceed with the methodological development of the empirical analysis focused on a selected sample (the first one hundred Italian companies listed as ordered by market capitalization / 2015). To this end, in order to test our assumptions, we provide the main statistical indicators as well as the pairwise correlations between our observed variables and then we proceed to the construction (and subsequent interpretation) of the econometric models elaborated in some variants.

A novelty of the paper is the proposal (in addition to a classical OLS) of a Structural Equations Model after a PCA with reference to the investigation of the relationship $\mathrm{BoD} /$ corporate performance / value (for the first time to our knowledge, introducing the concept of 'organizational convexity' as sum of given characteristics of the governing board commonly retained desirable), in consideration of the observable complexity and the systematic variables.

In this view, the revisited board characteristics represent the explanatory variables (predictors), while the corporate performance the response (regressed) variable. Once determined the most significant findings for the period (2014/2016; Italy), the paper closes with some ending notes of comment and bibliographic references.

\section{Theoretical Background: A Brief Overview and the Research Question}

It is well known that both internal factors (such as regulations, practice, corporate culture, business) and the external factors (some examples are represented by the development and the spreading of Corporate Governance Codes, the needs of foreign investors, the permeation of globalisation) contribute to the shaping of corporate governance in different ways; generally, in these models a contrasting approach between (relationship-based) insider system and (market-oriented) outsider system comes out [For further reference see: Charkham (1994); Hoskisson et al. (2004); Mayer (1997); Mayer (1998); Melis (1999); Rajan \& Zingales (2001); Roe (1994)].

In the first perspective (which is commonly found in the Italian system) ownership control is in the hands of a limited number of shareholders (generally, families or financial institutions), therefore majority shareholders are less likely to draw on risk capital market and control (Fiori \& Tiscini, 2005); in the second perspective, ownership is highly segmented and minority rights are safeguarded (e.g., in order to avoid rent extraction), as well as the capital market efficiency is developed. In Italy, empirical governance models (such as listed companies document) often become a hybrid phenomenon with dynamic transformation processes.

It is also known that the existing literature on governance distinguishes the shareholder view (or stockholder view) from the stakeholder view (Donaldson \& Preston, 1995; Freeman \& Reed, 1983; Freeman et al., 2010; Lazonick \& O'Sullivan, 2000; Letza et al., 2004): in the first definition, governance has a limited perspective (here, the Board of Directors conciliates the so-called "agency problems" between ownership and management, reducing agency costs by means of management monitoring procedures), while the second definition posits a broad perspective (in which governing bodies assess and adapt various and broad interests).

Considering the subject underlying the theoretical framework of this paper, it would be appropriate to review the main scientific studies more systematically.

In the first place, the studies about the so-called "Theory of Agency" (Jensen \& Meckling, 1976) should be mentioned. Here, starting from the separation between corporate ownership and control (a typical character of public corporations in the US; Berle \& Means, 1932), the analysis focused on the consequences arising from the different motivations that guide ownership (principal) and management representatives (agents). Furthermore, the following studies aimed at identifying the most suitable governance-based control dynamics by management bodies as by to mitigate the risk of opportunisms; these studies underline the importance of the $\mathrm{BoD}$ for executives monitoring (Fama \& Jensen, 1983; Eisenhardt, 1989).

Secondly, studies on "Stewardship Theory" claim no problems involving Executive Directors' motivations, since their actions are aimed at creating value and at enhancing corporate performance. In the light of this perspective, the core of this issue shifts from a suitable motivation by the management bodies to a more practical need to ensure structural conditions for companies, so that corporate goals can be achieved by means of a definite and authoritative governance, which can be possibly strengthened by the figure of managers, the latter carrying out executive activities. These 'agents', therefore, act as stewards who manage companies responsibly in order to enhance performance (Anderson et al., 2007; Davis et al., 1997; Donaldson \& Davis, 1991; Donaldson \& Preston, 1995; Donaldson, 1990; Mitchell et al., 1997). Considering a broader perspective, the stewardship view 
distances from the shareholder (one-principal) approach to join the stakeholder theory, especially when managers behave as 'agents' for multiple-principals (advocating 'drastic' social needs, too).

Though shaped by the above-mentioned theory, another approach deals with the studies about the so-called "Resource Dependency Theory" (Pfeffer \& Salancik, 1978); these studies meant to consider companies as open systems influenced by external factors. In this perspective, external factors deeply influence corporate organisation; in this sense, the Board's and management's role proves to be preeminent when it limits environment-related uncertainty, even by means of the acquisition and control of the so-called 'vital resources' (Barney, 1991; Hillman et al., 2009; Pfeffer, 1972; Zahra \& Pearce, 1989). Here the Board of Directors, with its distinctive features, becomes a valuable resource in a company.

In our case, a specific scientific focus can be found in the literature dealing with the organisation and operational principles of corporate bodies. In this approach, scientific research aims at finding any possible empirical connections between the Board of Directors' characteristics and company results, especially embracing an agency-based perspective. This framework, emphasising the existing connections between corporate governance and the resulting performance (part of this study) has been recently reconsidered after the recent global financial crisis (Francis, Hasan, \& Wu, 2012).

Basically, the Corporate Board (which is responsible for both compliance and performance) gives its contribution to corporate performance in an indirect and undefined way within its functions (that is, control / monitoring or check-and-balance, strategic programming and external service relations).

Some performance indicators found in the scientific literature are the budgetary indicators, in particular profitability indicator ratios (whose validity can be debatable, even though they still represent a valid benchmark since their validity is rated by the Boards of Directors) or the 'market value' indicators, such as equity market capitalisation, stock returns, empirical multipliers, etc.). (Zanda et al., 2013; Guatri \& Bini, 2009).

Agency theorists, in particular, state that an important task of a BoD is to supervise the management on behalf of shareholders; a correct monitoring, as a consequence, makes company performance improve even by mitigation of agency costs. Resource dependency theorists instead underline that a board is a provider of powerful and fruitful resources (e.g., legitimacy, advice and counsel, links to other organizations, etc.). In this light, Hillman \& Dalziel (2003) defines the 'board capital' a system of both human capital (experience, expertise, reputation) and relational capital (network of ties to other firms and external contingencies) which enables the provision of resources to the company and then increase performance. Such perspective is an evolution of the stewardship theory, where agents (directors and managers) are trustworthy stewards of the resources they have been entrusted (Donaldson \& Davis, 1991; who observed: «organisational role-holders are conceived as being motivated by a need to achieve, to gain intrinsic satisfaction through successfully performing inherently challenging work, to exercise responsibility and authority, and thereby to gain recognition from peers and bosses», p. 61).

Even though the existing scientific literature underlines the relationship between corporate board and firm performance (Nicholson \& Kiel, 2004), it is noteworthy that as for the importance of Board independence empirical findings are varied and dissimilar. In this sense, some studies reveal a non-existing significant relationship between the independence of corporate managers (albeit it still remains a cornerstone principle together with the 'sentencing role' of CEO duality; Fama \& Jensen, 1983; Jensen, 1993) and corporate results (Baysinger \& Butler, 1985; Bhagat \& Black, 2001; Hermalin \& Weisbach, 1991; Joseph et al., 2014; Mehran, 1995; Klein, 1998; Shivadsani \& Yermack, 1999). By contrast, a number of scholars underline the negative effect of this relationship (Agrawal \& Knoeber, 1996; Barnhart \& Rosenstein, 1998; Laux, 2008: in short, agency theory would support a large number of outside directors, while the resource theory would support boards with less number of outside directors). In addition, a positive feature associated with performance (though not universally occurring) should be the remarkable number of meetings, since it represents a supposed indicator of an enhanced attention, intensity and depth in managers' operations, mainly (yet not only) in the interest of shareholders (Vafeas, 1999). Other positive features (Sundaramurthy et al., 2013) are represented by educational qualification (granting higher competencies and performance), Director ownership (facilitating the personal interest in the growth of results and value) as well as the female presence in the boardroom (even as CEOs) - the latter being a potential way to enhance problem-solving, monitoring and strategy involvement attitudes (Hillman et al., 2007; Huse et al., 2009; Nielsen \& Huse, 2010a, 2010b); it also comes to represent an indicator of corporate social responsibility and a sign of inclusiveness, heterogeneity or diversity within a company (Fasan, 2012). Post and Byron (2015) find a female board representation related with positive sign to accounting results (while the link to market performance is near zero) especially in countries denoting higher shareholder protections. 
As regards the statistical incidence on corporate performance, Parbonetti (2006) examined some issues dealing with the establishment of governing bodies; earlier, Barontini and Caprio (2002) examined the BoD in the light of managers' turnover and corporate performance by providing a comparative analysis of Italian companies.

More recently, Marra (2013) studied how monitoring activities by the BoD are related to earnings quality as indicator of performance. In this sense, the scientific literature underlined that the independent directors have positive repercussions in terms of reducing (supposed) manipulating activities and therefore in terms of performance (Chahine \& Filatotchev, 2008; Klein, 2002; Peasnell et al., 2005), whereas CEO duality (Davidson et al., 2004; Dechow et al., 1996) would lead to unclear and contrasting evidence, similarly to results depending on the governing Board size (Beasley, 1996; Coles et al., 2008; Di Pietra et al., 2008; Eisenberg et al., 1998; Harford et al., 2008; Linck et al., 2008; Van den Berghe \& Levrau, 2004; Xie et al., 2003; Yermack, 1996). In the latter situation, the trade-off choice is between a developed decision-making competence and efficiency (which is more often found in small Boards of Directors, where lower is the risk of free riding and social loafing) and a larger number of directors (that could provide greater monitoring and advice) showing a more democratic nature as well as diversified competences, more commonly found in larger boards in compliance with the resource-based view.

To conclude, there are not concord findings and interpretations, valid universally. Therefore, the scrutinising of the (usually weak) influences of the Board of Directors' attributes to firm's performances must be contextualised with reference to a determined economic environment in a given, contingent period.

We use a classic regression model to deepen the recent Italian case and then propose, for the first time to our knowledge, an innovative Structural Equations Model as well as a new interpretation of the organisational 'contours' and 'array' of the governing board. We agree with Nicholson et al. (2012) that board's features (attributes and roles) impact on management performance and in turn on company results, while the context / situation contributes to model the board features. Other is the issue of performance evaluation of the board (Tricker \& Tricker, 2015). Moreover, Aguilera et al. (2015) highlight the importance of external governance mechanisms acting as independent forces (legal environment, market for corporate control, external auditing, stakeholder activism, media, etc.) as well as in conjunction with internal processes (the board of directors, along with the controlling owners, and managerial incentives, to complete the triangle).

Hence, the question of the research in a simple version is: Do (and eventually to what extent) the Board of Directors' characteristics systematically affect corporate results in a delicate context like the one examined?

From this research question (searching for the interrelations between the board characteristics and business performance) derive the hypotheses (better developed on the basis of the features of Italian listed companies described as follows) which fill an existing gap regarding the situationist analysis of a specific economy under a structural approach with latent and manifest variables: presumably from corporate boards and their adaptive processes to corporate performance indicators.

In light of the previous studies and of what common opinion could suggest, under a situationist approach, the null-hypothesis of our research to be eventually rejected can be formulated as follows: in the post-crisis context analysed, no significant correlation would subsist between Boards of Directors' characteristics and corporate performance.

3. Methods: Analysis of the Top 100 Listed Companies on the Italian Stock Exchange "Borsa Italiana" in Terms of Capitalisation

\subsection{Sample Analysed to Verify the Assumption of the Research}

To deepen the contingent relationship $\mathrm{BoD} /$ performance, we analysed a sample represented by the top 100 (as for market capitalization, 2015) listed firms on "Borsa Italiana": 38 companies are included in the FTSE Mib Index, while the remaining 62 in secondary Indices (FTSE Italia Mid Cap, STAR, and All Share). Few companies were discarded due to reduced capital stock price in the Stock Exchange and some newly listed companies for incomplete available data. The sample is representative of the major listed companies (also on similar European indices) and allegedly of the best boards and governance practices, worthy of great attention from investors, mainly due to the very remarkable market values involved.

Spencer Stuart (2015) analyses the same sample in its annual survey of Boards of Directors too. Our sample's structure for the year analysed is shown in Tab. 1; the highest economic relevance is for companies belonging to energy, banking and industrial sectors. 
Table 1. Structure of the empirical sample analysed

\begin{tabular}{lll}
\hline Sector & No. of companies & Market capitalisation \\
\hline Banking & 17 & $25 \%$ \\
Insurance & 7 & $9 \%$ \\
Industry & 25 & $17 \%$ \\
Consumer goods & 14 & $12 \%$ \\
Telecommunication & 7 & $4 \%$ \\
Energy & 15 & $28 \%$ \\
Other sectors & 15 & $5 \%$ \\
\hline
\end{tabular}

Note. Our elaboration of data.

As for the background of the Boards' members, almost $50 \%$ of them has a management-related derivation (most of them from business-related environments). As for gender is concerned, women represent only $20-25 \%$ of the overall number of directors. The average age of members is 58/59 (54 for women), while the average age for CEOs is 56/57 (64 for Chairmen). Almost all members are Italian.

The criterion of independence of corporate managers has been assessed pursuant to the Italian Legislative Decree no. 58 of 24 February 1998 - Consolidated Law on Financial Intermediation, and Corporate Governance Code as well. The following data show the representativeness of independent members in the sample analysed (Tab. 2).

Table 2. Relevance of independent board members

\begin{tabular}{llllllll}
\hline No. & $1-2$ & $3-4$ & $5-6$ & $7-8$ & $9-10$ & $11-12$ & $13+$ \\
\hline$\%$ & $4 \%$ & $36 \%$ & $29 \%$ & $16 \%$ & $7 \%$ & $4 \%$ & $4 \%$ \\
\hline
\end{tabular}

Note. Our elaboration of data.

They represent the majority in the Board especially in the MIB Index (42\%, while other Ftse Indices account for $10 \%$; considering the whole sample, $72 \%$ of verified cases show that independent members still represent a minority albeit an ongoing growing trend can be detected). Their spreading can be primarily found in the financial sectors (banking and insurance), followed by the service sector, industry and telecommunication. In this sense, it can be underlined that only $7 \%$ of Board Chairmen are totally independent (they are neither CEOs nor executives).

Another interesting result involving governance-related issues deals with the range of directorships carried out by Board members. The following table (Tab. 3) summarises the 'additional directorships' claimed by members in other companies:

Table 3. Number of 'additional directorships' claimed

\begin{tabular}{lllllllll}
\hline No. & 1 & 2 & 3 & 4 & 5 & 6 & 7 & $8+$ \\
\hline$\%$ & $39 \%$ & $18 \%$ & $13 \%$ & $8 \%$ & $6 \%$ & $4 \%$ & $3 \%$ & $9 \%$ \\
\hline
\end{tabular}

Note. Our elaboration of data.

Almost $50 \%$ of newly appointed Board members has a single directorship, thus providing evidence of a recent trend that prefers 'devoted' Board members who are presumably 'not easily influenced' by external conditioning.

As for the operations carried out by the Boards of Directors, the average number of meetings ranges from 11 to 12 per year (showing $92 \%$ of attendance); in the financial sectors, the number of meetings is higher also due to regulation-based duties to be satisfied. The sample includes more than 300 Board Committees (with an average of 3 committees per company). The most widespread Committees are Audit \& Risk and Compensation (followed by other Committees such as Executive, Related Party Transactions and Strategy).

Considering the nature of the sample and the theoretical information provided by reference studies, this survey on interrelations between corporate Boards and performance focuses on the least troubled post-crisis context (2014-2016) in order to avoid any possible bias or misrepresentation resulting from the crisis and its related 
scenarios.

Before our research-related discussions, an analysis of the statistical data arising from the variables that have been selected should be carried out (Tab. 4). In detail, as for corporate governance, we collected updated information and data on the following variables: overall number of members (Board of Directors' size); independent ratio; \% of women in the Board (gender diversity indicator); number of Board-related Committees; CEO Duality (a CEO acts also as Chairman); CEO age; members' additional directorships (interlocking indicator); number of annual meetings; existence of a female CEO. As for corporate performance, instead, the variables taken into account are the following: Price to Earnings; Earnings per share; Return on assets; Return oe equity; PEG ratio; cost of equity; Tobin's Q (proxied by the Market-to-Book ratio).

Several sources were used to gather data and information (corporate governance reports and financial statements issued by Italian Stock Market listed firms or exposed in the company websites; Consob, Italian public authority responsible for regulating the Italian financial markets;Spencer Stuart 2015 report; Capital IQ; Reuters Italia).

Table 4. Descriptive statistics

\begin{tabular}{lllll}
\hline Variable & Min & Max & Mean & Std deviation \\
\hline Board Size & 5 & 24 & 11.90 & 3.797 \\
\% Indep. & 0.00 & 0.89 & 0.4882 & 0.18146 \\
\% Women & 0.00 & 0.57 & 0.2245 & 0.09271 \\
No. of Board Committees & 1 & 7 & 3.17 & 1.118 \\
CeoDual & 0 & 1 & 0.18 & 0.381 \\
CEOAge & 39 & 79 & 56.72 & 8.842 \\
AddDirectorship & 0 & 80 & 25.63 & 20.456 \\
No. of Meetings & 4 & 30 & 11.35 & 5.511 \\
FemaleCEO & 0 & 1 & 0.05 & 0.210 \\
P/E & -14.99 & 354.74 & 25.5748 & 42.71556 \\
EPS & -2.53 & 6.07 & 0.5471 & 1.04751 \\
ROA & -0.0264 & 0.2116 & 0.037267 & 0.0411106 \\
ROE & -0.7875 & 0.5315 & 0.079958 & 0.1424090 \\
PEG exp5 & -20.00 & 600.51 & 11.8622 & 73.46723 \\
Tobin's Q & 0.05 & 13.50 & 1.9777 & 2.00953 \\
\hline
\end{tabular}

Note. Our elaboration of data.

Average data dealing with corporate Boards are shown above.

As for performance-related data is concerned, economic results from the sample are positive (thus providing evidence of a mitigation of the post-crisis scenario), showing an average P/E of 25.7, an EPS of 0.55, a PEG value of 11.9. Furthermore, profitability ratios are reasonable on average (showing a limited ability to create additional value).

\subsection{Specific Hypotheses of the Research}

Our null-hypothesis stated that in a post-crisis context like the one under consideration, no significant correlation would subsist between the Boards of Directors' characteristics and corporate performances. A rejection of the null-hypothesis would verify the existence of a correlation that, in such a peculiar context, we cannot imagine undifferentiated and indistinct due to the factors of uncertainty and complexity introduced by the previous crisis.

Indeed, considering the first and partial evidences and observations, at a glance, the research (sub-)hypotheses in our contingent situationist perspective can be stated as follows (deeming simplistic, superficial and debatable to claim that any Board-related enhancement would result however in an improvement of corporate results):

Hypothesis a): The Board size is interrelated to corporate performance. Yet, in view of any incongruities involving the international scenario and practices, it seems more likely to suppose barely positive or generally negative interrelations rather than fully positive interrelations in our context.

Hypothesis b): The Independent ratio is more likely to show an interrelation to corporate performance in the context analysed. Generally, a 'nominal' positive interrelation can be assumed (even in this case some 
incongruities emerge in the international scenario); nevertheless, independence might play a negative influence when it is not matched with competence.

Hypothesis c): The Board meetings number is more likely to show an interrelation to corporate performance in the context under investigation. In detail, unlike any preliminary intuition, the expected attitude of the interrelation should be mainly negative, favouring quality-based meetings (in terms of efficiency and effectiveness) rather than quantity-based meetings (in terms of actual number of meetings).

Hypothesis d): A remarkable number of Board Committees (with precise organisation and clear aims as well as mission) is more likely to show an interrelation to corporate performance in the context analysed. Considering preliminary tests, we would expect a negative interrelation to corporate results in line with hypothesis c).

Hypothesis e): The female presence in the boardroom and/or as CEO is more likely to show a (likely mild) impact on corporate results, considering the limited rate of gender diversity in the context analysed. In particular, the evidence indicates that these features would not enhance performance, in contrast to what has been assumed in an international perspective considering resource dependency.

Hypothesis f): Taking other Board features, we do not have elements to advance any significant and relevant effects. Nevertheless, the context under examination may show further systematic interrelations (both positive and/or negative) to corporate results, as eventually revealed by means of the overall inferential statistical analysis. So we do not exclude a priori accompanying effects.

\subsection{First Search for Correlations in the Investigated Sample}

Preliminarily, a paired examination of variables interrelations must be carried out (Tab. 5) in order to cope with the task dealing with the identification of a possible, systematic relationship between Board features and performance-related variables.

Table 5. Correlations matrix (pairwise)

\begin{tabular}{|c|c|c|c|c|c|c|c|c|c|c|c|c|c|c|c|}
\hline & $\begin{array}{l}\text { Board } \\
\text { Size } \\
\end{array}$ & $\begin{array}{l}\% \\
\text { Indep. }\end{array}$ & $\begin{array}{l}\% \\
\text { Women }\end{array}$ & $\begin{array}{l}\text { N.o of } \\
\text { Committ }\end{array}$ & CeoDual & CEOAge & $\begin{array}{l}\text { Add. } \\
\text { Dir.ship }\end{array}$ & $\begin{array}{l}\text { No. of } \\
\text { Meetings }\end{array}$ & $\begin{array}{l}\text { Female } \\
\text { CEO }\end{array}$ & $\mathrm{P} / \mathrm{E}$ & EPS & ROA & ROE & $\begin{array}{l}\text { PEG } \\
\exp \end{array}$ & Tobin's Q \\
\hline Board Size & 1 & .19 & -.090 & $.499 * *$ & $-.229 *$ & -.016 & $.515^{* *}$ & $.292 * *$ & -.093 & -.127 & -.102 & -.160 & -.046 & -.030 & $-.264 * *$ \\
\hline$\%$ Indep. & & 1 & $.255^{*}$ & $.442 * *$ & $-.341 * *$ & -.057 & -.074 & $.453 * *$ & .027 & -.103 & $-.213^{*}$ & $-.208^{*}$ & -.189 & -.056 & -.165 \\
\hline$\%$ Women & & & 1 & .012 & -.157 & -.116 & -.201 & .152 & -.041 & -.119 & $-.231^{*}$ & -.052 & .022 & -.055 & -.048 \\
\hline No. of Committ. & & & & 1 & $-.349^{* *}$ & .124 & .145 & $.446^{* *}$ & -.096 & -.108 & $-.222 *$ & $-.313^{* *}$ & $-.232 *$ & .072 & $-.379 * *$ \\
\hline CeoDual & & & & & 1 & $.222^{*}$ & -.043 & $-.277^{* *}$ & .043 & -.026 & .196 & $.289^{* *}$ & .194 & -.061 & $.294 * *$ \\
\hline CEOAge & & & & & & 1 & -.052 & -.055 & -.090 & -.174 & -.009 & -.200 & -.099 & -.005 & -.154 \\
\hline Add. Dir.ship & & & & & & & 1 & -.046 & -.043 & .019 & -.064 & .152 & -.031 & -.026 & -.081 \\
\hline No. of Meetings & & & & & & & & 1 & -.020 & -.131 & -.192 & $-.416^{* *}$ & $-.384 * *$ & .193 & $-.223^{*}$ \\
\hline Female CEO & & & & & & & & & 1 & .073 & -.034 & -.075 & $-.365^{* *}$ & -.031 & .036 \\
\hline $\mathrm{P} / \mathrm{E}$ & & & & & & & & & & 1 & $-.204 *$ & .035 & -.057 & -.054 & .027 \\
\hline EPS & & & & & & & & & & & 1 & $.450^{* *}$ & $.484 * *$ & -.067 & $.352 * *$ \\
\hline ROA & & & & & & & & & & & & 1 & $.493 * *$ & -.106 & $.557^{* *}$ \\
\hline ROE & & & & & & & & & & & & & 1 & -.025 & $.459 * *$ \\
\hline PEG exp & & & & & & & & & & & & & & 1 & -.098 \\
\hline Tobin's Q & & & & & & & & & & & & & & & 1 \\
\hline
\end{tabular}

Note. Our elaboration of data: ** Pearson Correlation significant at the 0.01 level (2-tailed); * Pearson Correlation significant at the 0.05 level (2-tailed).

As for correlations, from the analysis of the table shown above (and considering only statistically significant interrelations), we can draw that:

- The Board size denotes a positive interrelation to the Committees' number, to the overall additional directorships, and to the frequency of meetings; it shows a negative interrelation to CEO duality (a predictable interrelation). There is also a negative interrelation to Tobin's Q (and the other performance-related indicators, even though their statistically significance is low); this indicates that the Italian market is less likely to prefer large Boards in this delicate stage, perhaps due to the potential complexity for all Board members to reach common agreements, resulting in 'CEO-oriented' Boards in which CEOs decide at their complete discretion, to the detriment of purposeful debates; 
- Independent ratio shows a positive interrelation to the number of Committees, to the frequency of meetings and to gender diversity, as well as to CEO duality (predictable interrelations); on the other hand, it shows a negative interrelation to ROA and EPS (an additional analysis evidenced a positive interrelation to cost of equity);

- The female presence in the boardroom shows a negative interrelation to EPS; the same negative interrelation can be found between a female CEO and profitability ratios (especially ROE);

- $\quad$ The number of Committees denotes a positive interrelation to the number of meetings, while it shows an unclear positive interrelation to CEO duality; this may indicate the need for a 'resolute CEO' to settle critical governance-related issues. On the other hand, the same variable shows a negative interrelation to all performance-related indicators;

- The number of meetings shows a negative interrelations to outcome variables;

- CEO duality shows an unexpected positive interrelation to ROA and Tobin's Q (thus validating the stewardship view theory) and a negative interrelation to cost of equity.

It is important to underline that all interrelations are quite 'restrained' and do not cause problems in terms of multicollinearity in the econometric analysis below (as confirmed by the VIF test on variance inflation factors) that would bias regression coefficients for interpretation.

\section{Linear Regressions and Structural PLS Modeling: Research Results on the Interrelations between the Board Characteristics and Business Performance}

In this section we expose the results coming from the econometric analysis conducted in order to systematise the highlighted interrelationships within a 'unitary framework' that can simultaneously test our research hypotheses. Being essentially a cross-section matrix analysis (albeit extended over a two year period), the typical OLS (ordinary least squares) method is firstly properly operated (our first stage, while the second stage will adopt SEM). The independent variables are the above mentioned and described characteristics of the board, measured at 2014/2015, while the selected performance indicators represent the dependent variables, measured ex post at $2015 / 2016$ (to give the administrative characteristics the 'time' to be embedded in economic-financial performance of companies). Our variables are drawn from the mentioned accredited sources; they are mostly scaled by us in the cases of ratios variables; in some cases, because of the type of distribution of characteristics, occurrences and rule-practices among firms, there was no need to scale, and anyhow the structural modelling adopted (namely PLS), as known, does not require variables involved to be scaled.

\subsection{Stage I) OLS - Ordinary Least Squares Analysis}

Multiple regressions have been carried out providing as response variable each of the accounting and economic performance indicator mentioned above; that said, we report only the most interesting and robust findings, also in consideration of fitting levels generally adopted by the international practice.

Therefore, we perform the OLS model addressed to examine, in particular, the systematic correlations with ROA (return on equity version appeared a little less robust).

Table 6. OLS model, dependent variable: ROA

\begin{tabular}{lllll}
\hline & Coefficient & Std Beta & p-value & \\
\hline Const & 0,137488 & - & $<0,00001$ & $(* * *)$ \\
Tot directors & $-0,00154$ & $-0,147$ & 0,14698 & \\
Indep ratio & 0,008806 & 0,038 & 0,71614 & \\
Fem ratio & 0,011154 & 0,026 & 0,74595 & \\
N.o Comm & $-0,002539$ & $-0,071$ & 0,49145 & \\
CeoDual & 0,023729 & 0,232 & 0,10875 & \\
CeoAge & $-0,001215$ & $-0,269$ & 0,02871 & $(* *)$ \\
N.o Meet & $-0,002393$ & $-0,321$ & 0,00006 & $(* * *)$ \\
Fem Ceo & $-0,022106$ & $-0,107$ & 0,09601 & $(*)$ \\
Oth offices & 0,000521 & 0,260 & 0,07505 & $(*)$ \\
\hline
\end{tabular}


Regression Statistics:

\begin{tabular}{lclc}
\hline Sum Squared Errors & 0,0927 & Standard Error & 0,0343 \\
\hline$R$-squared & 0,3580 & Adjusted R-squared & 0,2850 \\
Durbin-Watson & 1,99 & $P$-value $(F)$ & $3,39 \mathrm{e}-07$ \\
\hline
\end{tabular}

Note. Our elaboration of data: $(* * *)$ level of significance $1 \% ;(* *)$ level of significance $5 \% ;\left(^{*}\right)$ level of significance $10 \%$. Heteroskedasticity robust standard errors.

Some remarkable findings can be identified as regards the variables related to age of the CEO $(* *)$, to the number of meetings per year $(* * *)$, to the number of other offices $(*)$ and to the presence of a CEO woman $(*)$ (see the next section for comments to the model), whose individual significance [sub $1 \%(* * *), 5 \%(* *)$ or $10 \%$ $(*)]$ is shown by the p-value associated with the individual regression coefficients.

It is worthwhile noting that the initial ROE variant model (often confirmed by several international studies), while identifying individual negative associations to the meetings frequency, to the CEO age and to the female $\mathrm{CEO}$, was by itself slightly less consistent from the significance viewpoint (F-statistics).

The restriction of the sample to firms falling under the MIB index (sub-sample made of the 40 highest capitalisation firms) denotes, in statistically significant terms, a negative relationship with the board size $(* *)$ and the CEO age $(*)$ and a positive linkage with the number of other offices (interlocks) $(* * *)$.

Turning from accounting results to the field of corporate valuation indicators as expressed by the relative stock market prices, first of all it is noted that the model based on the Tobin Q, although robust, showed a statistically significant negative coefficient with reference to the only variable of CEO age $(*)$ : for this reason, even for containment of the present work, the related detailed table is not reported. Similarly, the P/E, PEG, or EPS variant, however, do not produce more satisfying results.

Finally, our regression models were also corroborated by including control variables, such as the corporate size (natural logarithm of the number employees), the leverage ratio (mix of owners' equity and debt to finance operations) and a dummy variable for the financial rather than industrial sector, as by to account for any firm-specific effects. In the sample observed, such control variables were not statistically significant with reference to the performance measures since they produced not relevant changes. The company size appeared positively correlated (but with rejectable p-value), while the leverage ratio and the financial dummy appear negatively correlated to performance (again, with rejectable p-values). The omission / inclusion of the variables in question does not substantially affect the fitting tests of overall patterns, nor the individual regression coefficients and relating t-statistics. It is noteworthy only that the moderating effect of financial sector consisted of a more significant negative impact of the board size $\left(^{*}\right)$ and, especially, of a significant and negative effect of the CEO duality $(*)$ in accordance with agency advances (this implying that industrial firms, in turn, experienced a positive counterbalancing effect for this variable during the delicate and difficult period examined, likely in line with stewardship and resource-theories).

\subsection{Stage II) SEM/PLS - Structural Equations Model / Partial Least Squares Analysis}

After the first phase of the research involving several individual regressions (above), the second and more advanced stage was conducted to analyse more in depth the relationships between board qualities and corporate performance under a concurrent, comprehensive, structural model.

As a consequence, beforehand we carried out a Principal Component Analysis on the multiple features of the board, so as to control for the communalities (or common variance, in the present case at least equal to 0.5 ) and try to aggregate them where possible (see Tab. 7).

Communalities show the proportion of the variables' variance explainable by the principal components (the indicator, also known as $h^{2}$, expresses the sum of squared factor loadings). 
Table 7. Communalities of board attributes

\begin{tabular}{lll}
\hline Governance variable & Initial & Extraction \\
\hline Board size & 1,000 & 0,750 \\
Independent ratio & 1,000 & 0,668 \\
Female ratio & 1,000 & 0,475 \\
N.o Committees & 1,000 & 0,721 \\
CeoDual & 1,000 & 0,562 \\
CeoAge & 1,000 & 0,826 \\
Other offices & 1,000 & 0,743 \\
N.o Meetings & 1,000 & 0,582 \\
Female Ceo & 1,000 & 0,951 \\
\hline
\end{tabular}

Note. Extraction Method: Principal Component Analysis (PCA).

As known, the initial value of the communality in a PCA is 1, while the extraction values indicate the proportion of variance the principal components can explain (variables registering high values are well represented in the common factor space: in our case, we do not have any particularly low numbers).

A better interpretation of the factors is assured by a rotation procedure, as often used. Rotation determines a re-distribution of the tests' commonalities so that a clearer pattern of loadings might emerge. The objective is to find an arrangement in which tests load high on one factor and low on others. Rotation, therefore, shifts the factors until the most simple alignment with the tests is found.

By a Varimax rotation emerged initially four aggregated components with eigenvalues $>1$, able to explain $70 \%$ of the cumulative variance; however, our subsequent analysis by SEM suggested the inclusion of only one aggregate factor (the more robust one), obtained considering the characteristics of the governing board that follow (OC): CEO duality (in our case, the reverse non-duality: separation of CEO and Chair roles), independent ratio, frequency of meetings and number of committees.

This aggregate factor may express, to our opinion, a peculiar feature namable organisational convexity or functionally curving out board: it is a latent variable reflecting a strong analyticity, transparency and openness detectable in the board functionality structure (in this case, the governing boards count many independent directors, many meetings per year, many committees and a CEO not Chairman; the opposite situation, in a certain sense more "simplified", is namable organisational concavity inspired to synthesis and higher concentration of main competencies: in place of an extending outward board's array we have, in a figurative sense, a hollowed inward, curved-in, board of directors) [For an application of the concept of convexity and concavity to social science, see Hannan et al. (2003).] The remaining five characteristics, for they still recorded relevant coefficients in the other three major components, were accounted individually in the structural model in order to determine along with organisational convexity the overall grade of the board features impacting business performance. From the side of corporate performance, however, from the aggregate latent variable were in turn eliminated the weaker indicators, retaining the main three and more recognisable ones: ROA, ROE and Tobin Q (which are commonly appreciated in this type of analysis).

In brief, our Structural Equation Model predicts the existence of latent variables concurrently to the existence of manifest variables. The approach employed in our case - partial least squares, PLS - is the reflective one (under which, in consequence, the latent and unitary variable "performance" is reflected simultaneously in the three main indicators mentioned (Return on assets, Return on equity, Q); similarly the latent component OC "organisational convexity" is reflected in the four observed characteristics via PCA in addition to the other singularly examined board's features, named manifest variables). As known, Partial Least Squares path modeling is a variance-based structural equation procedure increasingly applied in business and social sciences (Henseler et al., 2016; Gelhard \& Von Delft, 2016).

The following diagram (Fig. 1) represents the structural model in question with its parameters: factor loadings (lambdas, outer model) and path loadings (betas, inner model). 


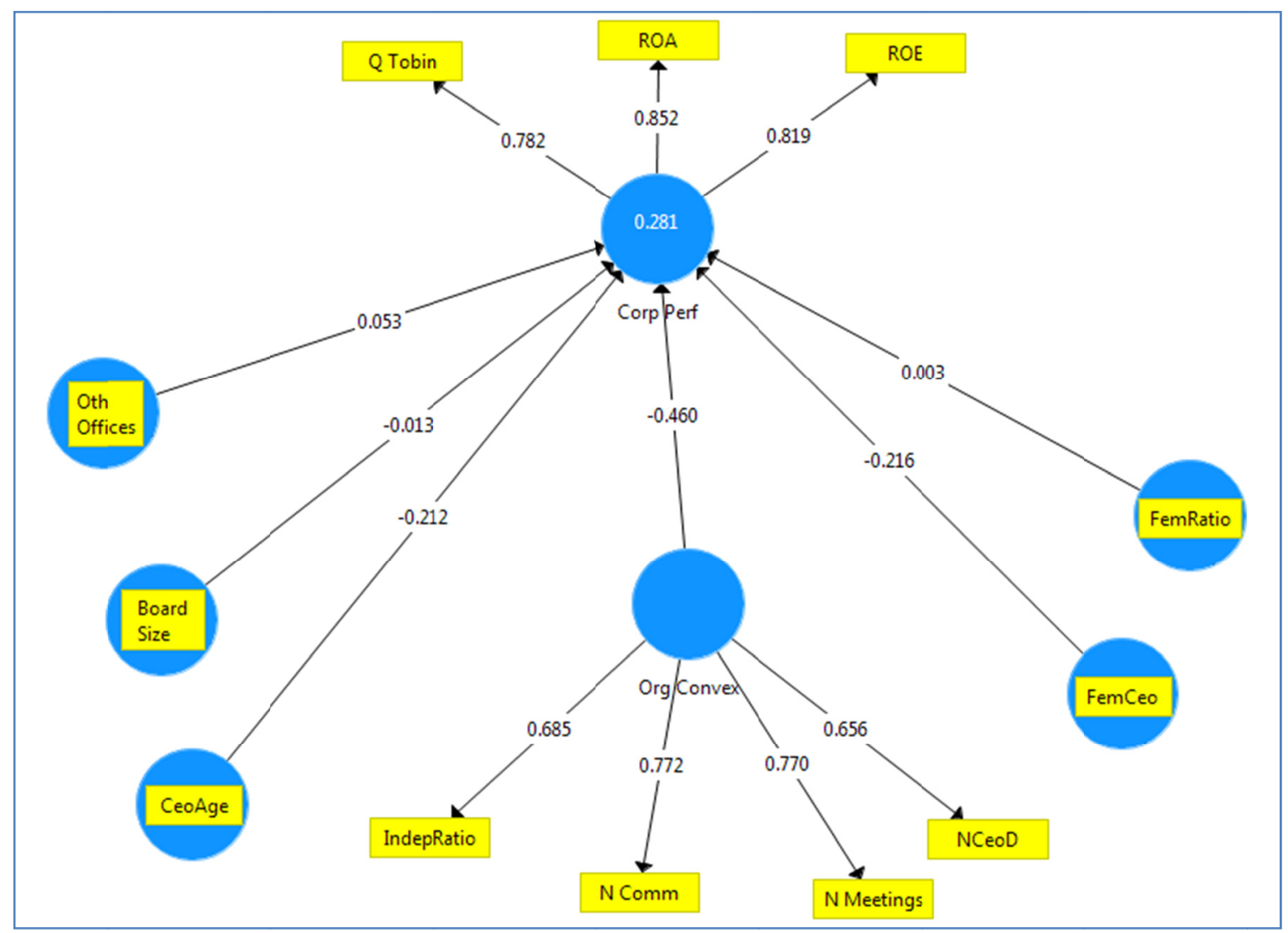

Figure 1. Structural equations model / PLS

Note. Our elaboration of data (Partial Least Squares; bootstrapping).

In the "graph", the reflective vectors between the latent and the manifest variables express the loadings coefficients (outer model). The contribution of corporate governance variables to performance instead is given by regressive vectors (inner model).

The diagram reports (Fig. 1) the regression coefficients; t-statistics were available after reiterative bootstrapping calculation (that is a resampling technique by a self-starting process used to obtain estimates significance).

The $p$-values of variables both inside OC (as for Independent ratio, Non-CeoDuality, N.o Meetings and N.o Committees) and from OC to Corp Perf, are excellent, showing a level of significance below $0.1 \%$; the same happens inside the latter latent variable (the higher $\mathrm{p}$-value is reflected by Tobin $\mathrm{Q}=0.001$; ROA and ROE have 0.000). P-values for both Ceo age and female Ceo are below 5\% (respectively 0.024 and 0.048 ), while Other offices are significant at 10\% (p-value 0.098). Only Board size and Female ratio have here p-values $>10 \%$, not statistically significant.

The overall reliability of the construct, as regards the "composed" latent variables, is evidenced by the acceptable values of CR - Composite Reliability (0.90 Corp Perf and 0.61 for OC: both greater than 0.59 , as required in exploratory research, they are judged satisfactory although the former, $>0.7$, appears more homogeneous than the latter, exploratory block 'convexity') (Bagozzi et al., 1998; Tseng et al., 2008), reassured by plausible Average Variance Extracted measures (AVEs equal respectively to 0.70 and 0.55 : since not $<0.50$, constructs are judged satisfactory (Götz et al., 2010)) to test Convergent Validity (that is, the communality of the construct) and appropriate rho-A values (between 0.70 and 0.80 ). Indeed, parameters are never below the critical values. Moreover, inside the latent performance figure reported is the R-squared (0.281, equals to the OLS' one).

Our grounded conceptual map concerning the BoD features as 'shaped' by the external environment solicitations (by markets and regulators / institutions, stakeholders and society) can be represented as follows (Figure 2). 


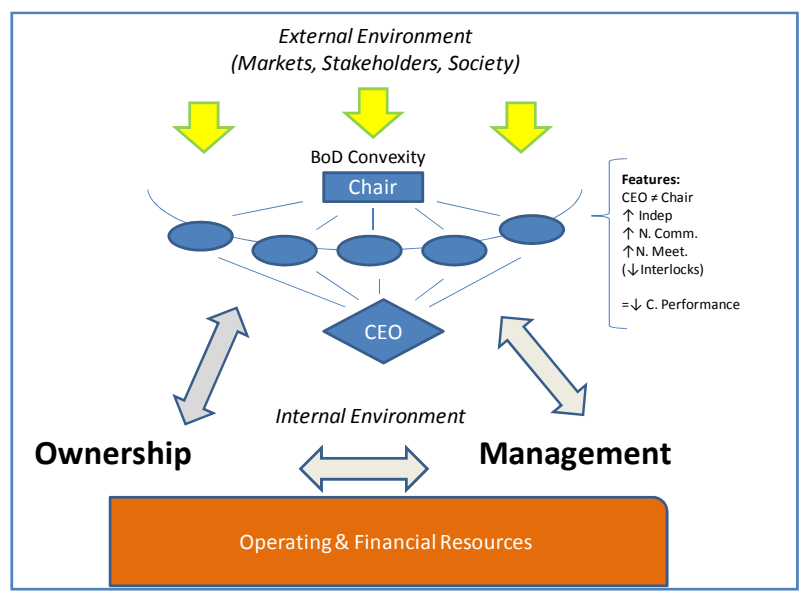

Figure 2. BoD's convexification

Note. Our conceptualization and map drawing.

Such that the external environment pressures, norms, requirements and influences would growingly shape the BoD's organization-array determining its virtual convexification, even in light of the predominant agency theories.

To be clearer, we may figure external forces like a liquid from the tap (environment) flowing into a vessel (BoD); as in physics, here the accelerating (decelerating) lever changes (meaning now threats now opportunities, turning on the tap in a strong or weak manner) make the governing boards' contours convex (concave). The next section will support this logic (see Fig. 3).

\section{Discussion}

The present research on the possible effect of the board of directors' characteristics on corporate performance, has focused on the first one hundred companies listed on "Borsa Italiana" (Italian Stock Exchange, part of London Stock Exchange Group), sorted by market capitalisation (as in 2015): n. 38 belong to the panel FTSE Mib; the remaining 62 are component of secondary indexes (Mid Cap, STAR, All Share). Our study, carried out in view of both theoretical and empirical research assumptions to be tested, is founded on the execution of one hundred multiple observations involving a dozen of data / information each time, for over a thousand data jointly processed, from 2014 to 2016.

Of particular interest are the econometric models, which show, in our case, a kind of 'concerted role' of the major characteristics of the board in determining - ceteris paribus - higher business (accounting and economic) performance.

The findings at an early stage of application of our models (in the "raw", basic version, upon data not adjusted) were more extensive than the final ones ("correct" or adjusted version): the presence of heteroskedasticity likely and usual in cross-sectional analysis - as ascertained by the White's test (with the Durbin-Watson statistics of spatial autocorrelation of residuals instead acceptable), however suggested to run OLS regressions performing heteroskedasticity robust standard errors. For the same reason, always adopting a prudent view, other variants of the statistical model (eg., the P/E) only apparently giving back appreciable inference, have been discarded from our deepening and reporting.

The input variables of the reported models are all validated by VIF (Variance Inflation Factors) control aiming to signal any (multi-)collinearity profiles, which would lower the quality of the findings, bringing effects / interpretations potentially misleading.

The accounting performance model, in particular, showed a negative association of profitability (ROA) with CEO age and with the frequency of meetings: in short, a younger CEO (while prefiguring more risk profiles, usually due to a more pronounced attitude to innovation and hazard), in the examined context - likely judged as expression of appreciated dynamism - seems to be a harbinger of new opportunities for the company, while the negative contribution of the meetings number can be reasonably attributed to specific situations in which the decision-making process of the governing board, whether time consuming and inefficient, can adversely affect the business performance (Consider, eg., the underlying presence of numerous or more complex management issues to be addressed in multiple meetings, or even the long collateral and informal activities for preparation 
and follow-up of $\mathrm{BoD}$ and Committees meetings). Negative is also the accounting performance association with the presence of female CEOs (a evidence that, however, is more likely affected by the low number of cases observed in Italy, where the CEO is usually a man); while positive the association with the other external offices of directors (additional directorships or interlocking indicator, a feature that may indicate experience, sharing, relationship). Slightly beyond the statistical rejection limit (as suggested by the White's test) is the positive association with the CEO duality (meaning that duality could help increase the day-to-day operational efficiency under the stewardship perspective, despite any possible conflict of interest: the decision-making advantages with a unified position seem to overcome disadvantages relating to a weaker management monitoring; in other words, all the board members can feel confident that the CEO/Chairman is fully aware of the firm's strengths and weaknesses along with what issues need to be addressed moving forward). (Note 3)

The economic performance pattern secondly highlighted with statistical significance the only negative association between the Tobin's Q and the CEO age (as if to show the contingent trust, or stake, of financial markets in younger CEOs); however, we obtained more interesting results by extending the economic performance model in view of the cost of equity (ex CAPM) and yearly value creation attitude. (Note 4)

Definitively, it should not be neglected that all the mentioned characteristics of the governing board were not always able to contribute - in a clear and direct way - to the improvement of each of the individual corporate performance indicators. For each performance measure, there was not an immediate transmission link, nor any guarantee of universal, recurrent and/or direct proportionality with the governance characteristics under consideration (sometimes a relationship appeared counterintuitive, implying a deterioration in the corporate performance rather than the hypothetical improvement, or vice versa).

Nonetheless, the R-squared (0.36), adjusted R-squared (0.28) and the F-test of the "individual" models ( $\mathrm{p}-\mathrm{v}=$ 3,39e-07) [Phase I of the research: OLS] show appreciable values that confirm the validity of the empirical analysis carried out, in terms of both the predictive ability of the models used and the overall adequacy of the theorised construct. In this regard, even the use of firm-specific control variables (corporate size, leverage ratio and sector dummy) did not affect the main findings.

The interpretation of the incidence of the board characteristics on the latent, compounded/unitary "performance" variable (being reflected simultaneously in the major individual indicators of corporate result), afterwards, was made possible thanks to the SEM approach (Phase II of the research: PLS). Also, as for the SEM fitting, the R-squared (equal to 0.28), the adjusted R-squared (equal to 0.24) and the SRMR (Standardised Root Mean Square Residual, 0.08; see Hu \& Bentler, 1998) appear acceptable (Goodness of Fit).

In the Structural Model, our evidence already identified finds further confirmation, gaining a greater coefficient of regression as for the negative impact on performance exerted both by the number of the meetings and by the separation of the CEO and Chair roles [indeed, stewardship theory suggests that the non-duality might obstacle unity and efficiency in decision-making mechanisms; Donaldson and Davis (1991); Finkelstein and D'Aveni (1994)] (Note 5); in addition, significant negative coefficients are attributable to the number of committees and to the independent ratio (note that the latter revealed weaker effects in individual regressions carried out in the first phase).

These features express in our SEM (thanks to PCA indications) the latent variable "organisational convexity" as the decentralisation attitude in business directorship (whose regression coefficient $=-0,46$ ). In our case, we derive that a more simplified (hollowed inward or curved-in; ie, convex upward or concave downward) organization-array of the $\mathrm{BoD}$ devoted to synthesis in decision-making, fluency and higher concentration of competencies (administrative / leadership centralisation in view of the alignment effect theory) makes, at least in a delicate period, a significant positive contribution to corporate results (more than an extending outward or curving-out BoD's functionality structure which might be highly inspired to analyticity, transparency, independent control and openness). That is, a "convexification" of board of directors contours and relating functions (decentralisation-oriented) allocation would not provide more value to firms. Milder yet not statistically significant coefficients are associated to the board size (negative sign) and to the rate of women (positive sign): the dimension of the governing body and the female representation would impact marginally and with low confidence. Most of the path coefficients in our PLS model are, nonetheless, justified by the t-statistics / p-values obtained by bootstrapping (especially our latent variables and related sub-variables show satisfactory significance levels).

In the light of what has so far been argued, we point out that some findings - in part already commented - appear as reliable in statistical terms as interesting and meaningful under the exquisitely business profile. A systemic reading of individual and structural empirical evidence identifies a single common denominator that, in 
substantive terms, seems to connect the performance of firms to the quality of administration and, more exactly, to the speed (readiness) of decision making in the governing board. The (counterintuitive) negative correlation between performance indicators and certain characteristics of the $\mathrm{BoD}$ - especially those attributable (directly or mediated) to the presence of situations of potential "weighting" (somehow burdening) in decision-making (such as a higher frequency of board meetings and the presence of a number of committees; and for the major companies, an increased number of directors) - suggests that the recent critical (Italian) economic situation (still characterised by instability) supports a review of practical corporate governance models geared especially to ensure a growing responsiveness / timeliness of the board in reacting to the stimuli and perils coming from the surrounding environment (to be considered, in particular, as the ability to adapt quickly, efficiently and effectively, the decisions taken on the basis of the market dynamics). At the same time, contrary to common expectations, companies seem to 'appreciate' the advantages (more than the disadvantages consideration) of both the CEO duality and lower (yet not marginal) rate of independent directors on the board (Note 6) - or, in one term, the benefits of an administrative and managerial leadership and aligned discretion (De Vries et. al., 1993; Peng et al. , 2007; Laux, 2008), at least in periods after a financial distress.

\section{Conclusion}

At the end of investigation, our hypothesis fully verified (statistically significant in the implemented modelling) is the one that negatively associates performance with the board's meetings frequency; other correlations, also negative, link performance to the age of the $\mathrm{CEO}$, to the proliferation of committees within the administrative board, to the presence of the CEO woman (although the latter evidence might be affected by the low occurrence of the phenomenon), and finally to the aforementioned independent ratio (known that independence, when not properly combined with the resource-competence, would adversely affect the economic results). Limited to the biggest firms, the board size denotes a negative association too.

The positive association between the corporate results (especially operational-accounting) and the additional directorships, instead, validate the doctrinal positions that emphasize the benefits of connections and collaborative relationships among members of different boards (appreciating interlocking directorate and networking advantages). We finally learn that the overall effect of the presence of women on the board would be positive although rather marginal and not significant.

In a nutshell, the original finding of the research consists in the ascertainment that - in the specific context of the late post-crisis period of investigation (2014/16: Italy) - corporate performance is higher in presence of an organisational concavity devoted to an efficiency-oriented synthesis, improved coordination and concentration of competencies in the same skilled and proactive hands (with a curved-in yet resilient, svelte and effective board of directors, rather than a more structured one; see Fig. 3). This allows a new and partly counterintuitive understanding of the contingent governance / performance combination, more in line both with a stewardship theory devoted to managerial empowerment and responsible control of corporate assets and with a resource-theory supporting co-optation to access, thanks to external links, to external resources for the firm.

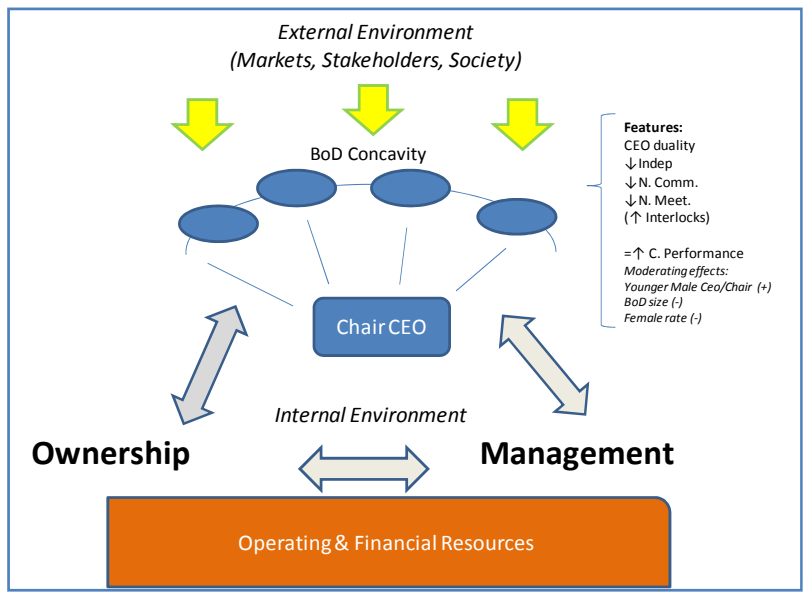

Figure 3. BoD's deconvexification

Note. Final conceptualization and map drawing. 
As said, the conceptual map figured above stems from the observation of the physical world (under the water/vessel metaphor): the external requirements, in line with the resource dependency theory, tend to shape the BoD's structure and functions drawing its organisational convexification (under a market-to-board approach), but, when the speed of pressures slows down even because the firm reacts and filters forces to shield from external forces and threats, the 'liquid surface' becomes concave. With other words, directors constituting the governing body would adopt a sort of 'entrenchment' behavior (moving towards a resource-based view and an upper echelon theory as well) addressed to safeguard corporate performance (under a board-to-market approach) Factors that support this can be identified in the following conditions: the $\mathrm{BoD}$ is a catalyst of corporate value, as the entire organisation an incubator of value; there is full confidence in the work and expertise of directors (and management staff as well) who responsibly denote active participation; directors have strong incentives and commitment (taking a leading strategy and policies-related function); as Donaldson \& Davis (1991, p. 51) would suggest, we expect a proactive «merging of individual ego and the corporation».

Drawing a kind of 'grounded theory', we may conclude that after a financial distress the organisational convexification (normally desired and designed corroborating the agency theory) will not enhance the corporate performance: a search for higher performance would suggest a deconvexification as far as possible and legitimate. The presence of interlocks will determine fruitful intersections between two or more (concave) boards of different companies. And interlocks propensity, in this case, would be in line with previous studies that see interlocking directorate as the consequence of adopted corporate strategies devoted to reduce environmental uncertainty (Schoorman et al., 1981).

The limitations of this research, basically to be identified in the perimeter of the sample and in the short-term dynamism, represent at once an opportunity soliciting an increase of the empirical observations both in terms of time (enlarging the survey, for instance with dummies associated with the crisis) and space (including other closer European markets such as France, Spain, Germany; of course taking into account the relative environmental factors effect, as Onesti (1995) would suggest).

It remains, in any case, the awareness (that is an insurmountable limit) that the $\mathrm{BoD}$ is a group of people who oversee the activities and affairs of a corporation. As a consequence, the real contribution of the directors to the accounting/economic performance - even being affected by undoubted connections with other dimensions of governance, with potential overlapping effect - depends also and especially by the actual mix of knowledge, information, power, attitude and personal/interpersonal behavior of individuals; ie, by the manner/style, entirely subjective (difficult to categorize and quantify), of co-directing now as a driver, now as a supervisor or (in broad sense) a trustee, the enterprise. (Note 7)

\section{Acknowledgements}

We are grateful to the Editors and the anonymous reviewers, whose precious comments have improved the substance of the paper.

\section{References}

Agrawal, A., \& Knoeber, C. R. (1996). Firm performance and mechanisms to control agency problems between managers and shareholders. Journal of Financial and Quantitative Analysis, 31(03), 377-397. http://dx.doi.org/10.2307/2331397

Aguilera, R. V., Desender, K., Bednar, M. K., \& Lee, J. H. (2015). Connecting the dots: Bringing external corporate governance into the corporate governance puzzle. Academy of Management Annals, 9(1), 483-573. http://dx.doi.org/10.1080/19416520.2015.1024503

Anderson, D. W., Melanson, S. J., \& Maly, J. (2007). The Evolution of Corporate Governance: power redistribution brings boards to life. Corporate Governance. An International Review, 15(5), 780-797. http://dx.doi.org/10.1111/j.1467-8683.2007.00608.x

Bagozzi, R. P., Yi, Y., \& Nassen, K. D. (1998). Representation of measurement error in marketing variables: Review of approaches and extension to three-facet designs. Journal of Econometrics, 89(1), 393-421. https://doi.org/10.1016/S0304-4076(98)00068-2

Barney, J. (1991). Firm resources and sustained competitive advantage. Journal of Management, 17(1), 99-120.

Barnhart, S. W., \& Rosenstein, S. (1998). Board composition, managerial ownership, and firm performance: An empirical analysis. Financial Review, 33(4). http://dx.doi.org/10.1111/j.1540-6288.1998.tb01393.x

Barontini, R., \& Caprio, L. (2002). Il Consiglio di Amministrazione, la rotazione degli amministratori e la performance dell'impresa: l'esperienza italiana in una prospettiva comparata. Rome: Istituto Poligrafico e 
Zecca dello Stato.

Baysinger, B. D., \& Butler, H. N. (1985). Corporate governance and the board of directors: performance effects of changes in board composition. Journal of Law, Economics and Organizations, 1(1), 101-124. https://doi.org/10.1093/oxfordjournals.jleo.a036883

Beasley, M. S. (1996). An empirical analysis of the relation between the board of director composition and financial statement fraud. Accounting Review, 71(4), 443-465. https://doi.org/10.2469/dig.v27.n2.79

Berle, A. A., \& Means, G. C. (1932). The modern corporation and property. New York: The McMillan Company.

Bhagat, S., \& Black, B. S. (2002). The non-correlation between board independence and long-term firm performance. Journal of Corporation Law, 27, 231-273. http://dx.doi.org/10.2139/ssrn.133808

Bianchi, L. A. (1996), «Corporate Governance». Considerazioni introduttive. Rivista delle Società, 41(2-3), 405-418.

Chahine, S., \& Filatotchev, I. (2008). The effects of information disclosure and board independence on IPO discount. Journal of Small Business Management, 46(2), 219-241. https://doi.org/10.1111/j.1540-627X.2008.00241.x

Charkham J. P. (1994). Keeping good company. A study of corporate governance in five countries. New York: Oxford University Press.

Coles, J. L., Daniel, N. D., \& Naveen, L. (2008). Boards: Does one size fit all?, Journal of Financial Economics, 87(2), 329-356. https://doi.org/10.1016/j.jfineco.2006.08.008

Davidson, W. N., Jiraporn, P., Kim, Y. S., \& Nemec, C. (2004). Earnings management following duality-creating successions: Ethnostatistics, impression management, and agency theory. Academy of Management Journal, 47(2), 267-275. https://doi.org/10.2307/20159577

Davis, J. H., Schoorman, F. D., \& Donaldson, L. (1997). Toward a stewardship theory of management. Academy of Management Review, 22(1), 20-47. https://doi.org/10.5465/AMR.1997.9707180258

De Vries, M. F. K., Miller, D., \& Noël, A. (1993). Understanding the leader-strategy interface: Application of the strategic relationship interview method. Human Relations, 46(1), 5-22. http://dx.doi.org/abs/10.1177/001872679304600102

Dechow, P. M., Sloan, R. G., \& Sweeney, A. P. (1996). Causes and consequences of earnings manipulation: An analysis of firms subject to enforcement actions by the SEC. Contemporary Accounting Research, 13(1), 1-36. https://doi.org/10.1111/j.1911-3846.1996.tb00489.x

Di Pietra, R., Grambovas, C. A., Raonic, I., \& Riccaboni, A. (2008). The effects of board size and 'busy'directors on the market value of Italian companies, Journal of Management \& Governance, 12(1), 73-91. https://doi.org/10.1007/s10997-008-9044-y

Donaldson, L. (1990). The ethereal hand: Organizational economics and management theory. Academy of Management Review, 15(3), 369-381. https://doi.org/10.2307/258013

Donaldson, L., \& Davis, J. H. (1991). Stewardship theory or agency theory: CEO governance and shareholder returns. Australian Journal of management, 16(1), 49-64. https://doi.org/10.1177/031289629101600103

Donaldson, T., \& Preston, L. E. (1995). The Stakeholder Theory of The Corporation: Concepts, Evidence, and Implications. Academy of Management Review, 20(1), 65-91. https://doi.org/10.2307/258887

Eisenberg, T., Sundgren, S., \& Wells, M. T. (1998). Larger board size and decreasing firm value in small firms, Journal of Financial Economics, 48(1), 35-54. https://doi.org/10.1016/S0304-405X(98)00003-8

Eisenhardt, K. M. (1989). Agency theory: An assessment and review. Academy of Management Review, 14(1), 57-74. https://doi.org/10.2307/258191

Fama, E.F., \& Jensen, M.C. (1983). Separation of ownership and control. The Journal of Law \& Economics, 26(2), 301-325. https://doi.org/10.2139/ssrn.94034

Finkelstein, S., \& D'aveni, R. A. (1994). CEO duality as a double-edged sword: How boards of directors balance entrenchment avoidance and unity of command. Academy of Management journal, 37(5), 1079-1108. https://doi.org/10.2307/256667

Fiori, G., \& Tiscini, R. (2005). Corporate governance, regolamentazione contabile e trasparenza 
dell'informativa aziendale. Milan: FrancoAngeli.

Fortuna, F. (2001). Corporate governance, soggetti, modelli e sistemi. Milan: FrancoAngeli.

Francis, B., Hasan, I., \& Wu, Q. (2012). Do corporate boards affect firm performance? New evidence from the financial crisis. Bank of Finland Research, 11. https://doi.org/10.2139/ssrn.2041194

Freeman, R. E., \& Reed, D. L. (1983). Stockholders and stakeholders: A new perspective on corporate governance. California Management Review, 25(3), 88-106. https://doi.org/10.2307/41165018

Freeman, R. E., Harrison, J. S., Wicks, A. C., Parmar, B. L., \& De Colle, S. (2010). Stakeholder theory: The state of the art. Cambridge University Press. https://doi.org/10.1017/CBO9780511815768

Fuzi, S. F. S., Halim, S. A. A., \& Julizaerma, M. K. (2016). Board Independence and Firm Performance. Procedia Economics and Finance, 37, 460-465. https://doi.org/10.1016/s2212-5671(16)30152-6

Gelhard, C., \& Von Delft, S. (2016). The role of organizational capabilities in achieving superior sustainability performance. Journal of Business Research, 69(10) 4632-4642. https://doi.org/10.1016/j.jbusres.2016.03.053

Gillan, S. L. (2006). Recent developments in corporate governance: An overview. Journal of Corporate Finance, 12(3), 381-402. https://doi.org/10.1016/j.jcorpfin.2005.11.002

Götz, O., Liehr-Gobbers, K., \& Krafft, M. (2010). Evaluation of structural equation models using the partial least squares (PLS) approach. In Handbook of partial least squares (pp. 691-711). Springer Berlin Heidelberg. https://doi.org/10.1007/978-3-540-32827-8_30

Guatri, L., \& Bini, M. (2009). Nuovo trattato sulla valutazione delle aziende. Milan; UBE.

Hannan, M. T., Carroll, G. R., \& Pólos, L. (2003). The organizational niche. Sociological Theory, 21(4), 309-340. https://doi.org/10.1046/j.1467-9558.2003.00192.x

Harford, J., Mansi, S. A., \& Maxwell, W. F. (2008). Corporate governance and firm cash holdings in the US. Journal of Financial Economics, 87(3), 535-555. https://doi.org/10.1016/j.jfineco.2007.04.002

Henseler, J., Hubona, G., \& Ray, P. A. (2016). Using PLS path modeling in new technology research: updated guidelines. Industrial Management \& Data Systems, $116(1), \quad 2-20$. https://doi.org/10.1108/imds-09-2015-0382

Hermalin, B. E., \& Weisbach, M. S. (1998). Endogenously chosen boards of directors and their monitoring of the CEO. The American Economic Review, 88(1), 96-118.

Hillman, A. J., \& Dalziel, T. (2003). Boards of directors and firm performance: Integrating agency and resource dependence perspectives. The Academy of Management review, 28(3), 383-396. https://doi.org/10.2307/30040728

Hillman, A. J., Shropshire, C., Cannella, A. A. (2007). Organizational predictors of women on corporate boards. Academy of Management Journal, 50(4), 941-952. https://doi.org/10.5465/amj.2007.26279222

Hillman, A. J., Withers, M. C., \& Collins, B. J. (2009). Resource Dependence Theory: A Review. Journal of Management, 35(6), 1404-1427. https://doi.org/10.1177/0149206309343469

Hoskisson, R., Yiu, D., \& Kim, H. (2004). Corporate governance systems: effects of capital and labor market congruency on corporate innovation and global competitiveness, The Journal of High Technology Management Research, 15, 293-315. https://doi.org/10.1016/j.hitech.2004.03.008

Hu, L. T., \& Bentler, P. M. (1998). Fit indices in covariance structure modeling: Sensitivity to under parameterized model misspecification. Psychological Methods, $3(4), \quad 424$. https://doi.org/10.1037//1082-989x.3.4.424

Huse, M. (2007). Boards, governance and value creation: The human side of corporate governance. Cambridge: Cambridge University Press. https://doi.org/10.1017/cbo9780511611070

Huse, M., Nielsen, S. T., \& Hagen, I. M. (2009). Women and Employee-Elected Board Members, and Their Contributions to Board Control Tasks, Journal of Business Ethics, 89(4), 581-597. https://doi.org/10.1007/s10551-008-0018-4

Jensen M. C. (1993). The modern industrial revolution, exit, and the failure of internal control systems. The Journal of Finance, 48(3), 831-880. https://doi.org/10.2307/2329018

Jensen, M. C., \& Meckling, W. H. (1976). Theory of the firm: Managerial behavior, agency costs and ownership 
structure. Journal of Financial Economics, 3(4), 305-360. https://doi.org/10.1016/0304-405x(76)90026-x

Joseph, J., Ocasio, W., \& McDonnell, M.H. (2014). The structural elaboration of board independence: Executive power, institutional logics, and the adoption of CEO-only board structures in US corporate governance. Academy of Management Journal, 57(6), 1834-1858. https://doi.org/10.5465/amj.2012.0253

Klein, A. (1999). Firm performance and board committee structure. The Journal of Law and Economics, 41(1), 275-304. https://doi.org/10.1086/467391

Klein, A. (2002). Audit committee, board of director characteristics, and earnings management. Journal of Accounting and Economics, 33(3), 375-400. https://doi.org/10.1016/s0165-4101(02)00059-9

Laux, V. (2008). Board independence and CEO turnover. Journal of Accounting Research, 46(1), 137-171. https://doi.org/10.1111/j.1475-679x.2008.00269.x

Lazonick, W., \& O'Sullivan, M. (2000). Maximizing shareholder value: a new ideology for corporate governance. Economy and society, 29(1), 13-35. https://doi.org/10.1080/030851400360541

Letza, S., Sun, X., \& Kirkbride, J. (2004). Shareholding versus stakeholding: A critical review of corporate governance. Corporate Governance: An International Review, 12(3), 242-262. https://doi.org/10.1111/j.1467-8683.2004.00367.x

Linck, J. S., Netter, J. M., \& Yang, T. (2008). The determinants of board structure. Journal of Financial Economics, 87(2), 308-328. https://doi.org/10.1016/j.jfineco.2007.03.004

Marra, A. (2013). Consigli di amministrazione delle società quotate e qualità degli utili in Italia: Un'analisi empirica nell'era IFRS. Milan: Egea.

Mayer, C. (1997). Corporate Governance, Competition, and Performance. Journal of Law and Society, 24(1), 152-176. https://doi.org/10.1111/1467-6478.00041

Mayer, C. (1998). Financial Systems and Corporate Governance: A Review of The International Evidence. Journal of Institutional and Theoretical Economics, 144-165.

Mehran, H. (1995). Executive compensation structure, ownership, and firm performance. Journal of financial economics, 38(2), 163-184. https://doi.org/10.1016/0304-405x(94)00809-f

Melis, A. (1999), Corporate governance. Un'analisi empirica della realtà italiana in un'ottica europea. Turin: Giappichelli.

Mitchell, R. K., Agle, B. R., \& Wood, D. J. (1997). Toward a theory of stakeholder identification and salience: Defining the principle of who and what really counts. Academy of Management Review, 22(4), 853-886. https://doi.org/10.5465/amr.1997.9711022105

Nicholson, G. J., \& Kiel, G. C. (2004). A framework for diagnosing board effectiveness. Corporate Governance: An International Review, 12(4), 442-460. https://doi.org/10.1111/j.1467-8683.2004.00386.x

Nicholson, G., Kiel, G., \& Tunny, J. A. (2012). Board evaluations: Contemporary thinking and practice. The SAGE Handbook of Corporate Governance, 285-324. http://dx.doi.org/10.4135/9781446200995.n14

Nielsen, S., \& Huse, M. (2010a). The Contribution of Women on Boards of Directors: Going beyond the Surface, Corporate Governance: An International Review, 18(2), 136-148. https://doi.org/10.1111/j.1467-8683.2010.00784.x

Nielsen, S., \& Huse, M. (2010b). Women directors' contribution to board decision-making and strategic involvement: The role of equality perception. European Management Review, 7(1), 16-29. https://doi.org/10.1057/emr.2009.27

Onesti, T. (1995). 'Fattori Ambientali' e comportamenti contabili. Analisi comparata dei sistemi contabili di alcuni paesi industrializzati. Turin: Giappichelli.

Onesti, T., Angiola, N., Martini, S. B., Garzella, S., \& Muserra, A. L. (2013). Strategie di sviluppo aziendale, processi di corporate governance e creazione di valore: Teorie, analisi empiriche ed esperienze a confronto. Milan: FrancoAngeli.

Parbonetti, A. (2006). Corporate governance. Problemi di configurazione dell'organo di governo e riflessi sugli andamenti aziendali. Milan: Giuffrè.

Peasnell, K. V., Pope, P. F., \& Young, S. (2005). Board monitoring and earnings management: Do outside directors influence abnormal accruals? Journal of Business Finance \& Accounting, 32(7-8), 1311-1346. 
https://doi.org/10.1111/j.0306-686x.2005.00630.x

Peng, M. W., Zhang, S., \& Li, X. (2007). CEO duality and firm performance during China's institutional transitions. Management and Organization Review, 3(2), 205-225. https://doi.org/10.1111/j.1740-8784.2007.00069.x

Pfeffer, J. (1972). Size and Composition of Corporate Boards of Directors: The Organization and its Environment. Administrative Science Quarterly, 17, 218-229. https://doi.org/10.2307/2393956

Pfeffer, J., \& Salancik, G. R. (1978). The External Control of Organisations: A Resource Dependence Perspective. New York: Harper \& Row.

Post, C., \& Byron, K. (2015). Women on boards and firm financial performance: A meta-analysis. Academy of Management Journal, 58(5), 1546-1571. https://doi.org/10.5465/amj.2013.0319

Rajan, R. G., \& Zingales, L. (2001). Financial Systems, Industrial Structure, and Growth. Oxford Review of Economic Policy, 17(4), 467-482. https://doi.org/10.1093/oxrep/17.4.467

Roe, M. J. (1994), Strong managers, weak owners: the political roots of American corporate finance, Princeton: Princeton University Press. https://doi.org/10.1515/9781400821389

Schoorman, F. D., Bazerman, M. H., \& Atkin, R. S. (1981). Interlocking Directorates: A Strategy for Reducing Environmental Uncertainty. The Academy of Management Review, 6(2), 243-251. https://doi.org/10.2307/257880

Shapiro, D., Tang, Y., Wang, M., \& Zhang, W. (2015). The effects of corporate governance and ownership on the innovation performance of Chinese SMEs. Journal of Chinese Economic and Business Studies, 13(4), 311-335. http://dx.doi.org/10.1080/14765284.2015.1090267

Shivdasani, A., \& Yermack, D. (1999). CEO involvement in the selection of new board members: An empirical analysis. The Journal of Finance, 54(5), 1829-1853. https://doi.org/10.1111/0022-1082.00168

Shleifer, A., \& Vishny, R. W. (1997). A survey of corporate governance. The Journal of Finance, 52(2), 737-783. https://doi.org/10.2307/2329497

Spencer Stuart (2015). Italia Board Index. Osservatorio sui Consigli di Amministrazione delle società quotate Italiane. Milan-Rome.

Sundaramurthy, C., Pukthuanthong, K., \& Kor, Y. (2013). Positive and negative synergies between the CEO's and the corporate board's human and social capital: A study of biotechnology firms. Strategic Management Journal, 35(6), 845-868. https://doi.org/10.1002/smj.2137

Tricker, R. B., \& Tricker, R. I. (2015). Corporate governance: Principles, policies, and practices. Oxford University Press.

Tseng, M. L., Wu, W. W., Lin, Y. H., \& Liao, C. H. (2008). An exploration of relationships between environmental practice and manufacturing performance using the PLS path modeling. WSEAS Transactions on Environment and Development, 4(6), 487-502.

Turnbull, S. (1997). Corporate governance: Its scope, concerns and theories. Corporate Governance: An International Review, 5(4), 180-205. https://doi.org/10.1111/1467-8683.00061

Vafeas, N. (1999). Board meeting frequency and firm performance. Journal of Financial Economics, 53(1), 113-142. https://doi.org/10.1016/s0304-405x(99)00018-5

Van den Berghe, L. A., \& Levrau, A. (2004). Evaluating boards of directors: what constitutes a good corporate board? Corporate Governance: An International Review, 12(4), 461-478. https://doi.org/10.1111/j.1467-8683.2004.00387.x

Xie, B., Davidson, W. N., \& DaDalt, P. J. (2003). Earnings management and corporate governance: the role of the board and the audit committee. Journal of Corporate Finance, 9(3), 295-316. https://doi.org/10.1016/s0929-1199(02)00006-8

Yermack, D. (1996). Higher market valuation of companies with a small board of directors. Journal of Financial Economics, 40(2), 185-211. https://doi.org/10.1016/0304-405x(95)00844-5

Zahra, S. A., \& Pearce, J. A. (1989). Boards of directors and corporate financial performance: A review and integrative model. Journal of Management, 15(2), 291-334. https://doi.org/10.1177/014920638901500208

Zanda, G., Lacchini, M., \& Onesti, T. (2013). La valutazione delle aziende. Turin: Giappichelli. 
Zattoni, A. (2015). Corporate Governance. Milan: Egea.

Zingales, L. (2008). Corporate Governance. In Durlauf, S. N., \& Blume, L. E. (Eds), New Palgrave Dictionary of Economics and the Law, Palgrave Macmillan. https://doi.org/10.1057/9780230226203.0323

\section{Notes}

Note 1. The paper provides in substance an exploratory study since it investigates a complex interrelationship already deepened in literature but through new lenses (under a new approach); therefore it may require further validation in future research.

Note 2. The concept of corporate governance can be declined and examined according to different paradigms, depending on the purpose of study and on the different perspective with which the company and its actual functioning in the environment where it operates can be analysed. In very schematic terms, the significance of corporate governance can be understood firstly in the strict sense, as a set of institutions and rules (most notably relating to the system of internal organs, such as the board of directors), aimed at ensuring an effective, efficient and fair corporate governance to people who interact with the company itself; secondly in the broad sense, taking into account also the conditions that characterise the (external) environment in which companies operate (Fortuna, 2001; White, 1996). This paper welcomes the meaning of corporate governance in the narrow sense.

Note 3. The preceding OLS model, once 'moderated' by the sector dummy, demonstrated for financial / banking firms of our sample a negative impact of the CEO duality instead: hence, in this sector, the conflict of interest, the opportunistic behavior and the possible self-serving and extraction of private benefits of control seem to give markets and stakeholders more concern, in line with the principal / agent theory. Since the financial sub-sample is less numerous, the global effect (pushed by industrial corporation) is positive: hence, the global agency effect is moderated.

Note 4. The econometric analysis was also corroborated by the study of the cost of equity. We identified a positive association between the cost of equity (calculated via CAPM), on the one hand, and the board size, the number of meetings and committees on the other. The boards characters seemed relating simultaneously to an increase in fair remuneration of equity capital because of the potential conflicts between directors (also due to the board size) and, ultimately, the lower rapidity of the decision-making and corporate governance processes. This extension of the OLS model was also developed in a (value creation) GLM logistic model with "limited dependent variable". The LOGIT model, in particular, revealed that the intensification of the board meetings did not contribute to increase the chances of the company to create additional value, measured, in our case, by means of the spread rate between profitability and return on capital. Similarly, ceteris paribus, the presence (still 'rare' in the Italian practice) of a female CEO.

Note 5. Similar findings from empirical research have been recently advanced, in some cases, for State Ownership Enterprises and Family Firms (Shapiro et al., 2015). In Italy, even for businesses listed on the Stock Exchange, a very high rate of companies (more than 50\%) are family firms; besides, there are some SOE listed too.

Note 6 . Our sample counts 3 to 6 independent directors in $65 \%$ of cases; on average, the dependent ratio is almost $50 \%$ of the board size. This reveal that performance is higher when the independent ratio is not too large. Fuzy et al. (2016) recently found that a very high rate of independents would not ensure the increase of firm performance, which, sometimes, by contrast, shows to be negatively related.

Note 7. Another unavoidable 'limit' resides in the awareness that the performance and corporate governance indicators tested in the study do not exhaust the category of "possible" indicators (without saying that it would be improvident and far-fetched to believe to judge the corporate governance/performance permanently, absolutely on the basis of a given 'closed' set of indicators). Among the variables that could supplement or improve this type of analysis we can mention other features of the board itself (eg., ownership rate or incentives), or, more broadly, other dimensions of corporate governance (the whole ownership structure characters and related rights; the internal control system; information and disclosure).

\section{Copyrights}

Copyright for this article is retained by the author(s), with first publication rights granted to the journal.

This is an open-access article distributed under the terms and conditions of the Creative Commons Attribution license (http://creativecommons.org/licenses/by/4.0/). 